\title{
TARI DOLALAK SEBAGAI BENTUK PENDEKATAN KEARIFAN LOKAL DAN BUDAYA (KALBU) PADA MATA PELAJARAN BIOLOGI
}

\author{
FAJAR ADINUGRAHA \\ Dosen Pendidikan Biologi, Universitas Kristen Indonesia \\ fajar.adinugraha@uki.ac.id
}

\begin{abstract}
ABSTRAK
Penelitian ini bertujuan untuk 1) menjelaskan perkembangan Tari Dolalak di Kabupaten Purworejo, 2) menganalisis ranah nilai sikap, spiritual dan Penguatan Pendidikan Karakter (PPK) yang terkandung dalam Tari Dolalak, 3) menganalisis ranah pengetahuan Tari Dolalak yang diintegrasikan dalam pelajaran Biologi. Tari Dolalak merupakan tari yang berasal dari Kabupaten Purworejo yang merupakan bentuk akulturasi budaya. Metode penelitian merupakan studi pustaka studi pustaka dari beberapa literatur (analisis isi). Studi literatur dilakukan dengan menganalisis mengenai kearifan lokal dan budaya di kabupaten Purworejo yaitu Tari Dolalak. Tari Dolalak mengalami perkembangan antara lain: 1) jenis tarian, 2) syair, 3) pakaian/ kostum, 4) formasi pemain, dan 5) pementasan. Berdasarkan analisis 3 (tiga) syair Dolalak yaitu Jalan-Jalan, Ambil Kain, dan Pagi-Pagi, maka dapat dijelaskan bahwa Tari Dolalak mengandung nilai-nilai yang terkandung dalam Kurikulum 2013 yaitu ranah sikap sosial dan spiritual yaitu jujur, disiplin, tanggung jawab, toleransi, gotong royong, santun, dan percaya diri. Selain itu, mengandung nilai Penguatan Pendidikan Karakter (PPK) yaitu religius, nasionalisme, mandiri, gotong royong, dan integritas. Berdasarkan analisis gerakan dan perlengkapan Tari Dolalak, maka dapat dijelaskan bahwa Tari Dolalak dapat diintegrasikan dalam ranah pengetahuan dan keterampilan. Ranah pengetahuan dan keterampilan ini meliputi materi keanekaragaman hayati, plantae, animalia, dan sistem gerak.
\end{abstract}

Kata kunci: tari dolalak, kearifan lokal dan budaya, pendekatan kalbu, biologi, kurikulum 2013

\section{PENDAHULUAN}

Biologi merupakan salah satu mata pelajaran karakteristik dari peminatan MIPA (Matematika dan Ilmu Pengetahuan Alam) di SMA. Cakupan materi Biologi antara lain: keanekaragaman hayati (protista, jamur, tumbuhan, dan hewan), mikrobiologi (virus, bakteri), ekologi, lingkungan, morfologi, fisiologi, anatomi, biokimia, genetika, evolusi, dan bioteknologi. Dengan kata lain, Biologi merupakan 
pelajaran yang menggunakan alam sekitar siswa sebagai sumber belajar.

Umumnya, pembelajaran Biologi meliputi teori dan praktikum. Namun, waktu yang terbatas membuat pembelajaran Biologi hanya mengejar materi dan tidak menggunakan alam sekitar untuk mempelajari Biologi. Salah satu kekayaan alam sekitar yang bisa digunakan sebagai sumber belajar adalah kearifan lokal dan budaya setempat.

Kearifan lokal dan budaya merupakan sebuah warisan yang mengandung nilai-nilai luhur dan pengetahuan yang bisa dijadikan referensi dalam pembelajaran. Menurut penelitian Pieter (2017:111), dalam memanfaatkan kearifan lokal dan budaya, guru dapat mengadaptasi kerangka kajian sosiokultural dalam pendidikan. Proses integrasi kearifan lokal dalam pengajaran dapat dilakukan dengan cara enkulturasi, asimilasi dan asimilasi. Dampak dari pengintegrasian kearifan sains lokal dalam pengajaran sains akan mempermudah siswa untuk mengkronstruksi konsep sains modern dan tetap mempertahankan kearifan lokal budaya masing-masing suku bangsa.

Pendekatan Kearifan Lokal dan Budaya atau yang disingkat oleh penulis menjadi Pendekatan KALBU ini merupakan pendekatan yang mengintegrasikan kearifan lokal dan budaya yang terdapat di daerah di mana siswa tersebut belajar. Pendekatan ini merupakan sebuah pendekatan yang bertujuan untuk mengingat kembali serta merelfeksikan diri bahwa pengetahuan sudah ada jauh sebelum pendidikan formal masuk ke Indonesia.

\section{Pendekatan Kearifan Lokal} dan Budaya (KALBU) sangat penting di tengah lunturnya nilainilai kearifan lokal dan budaya yang ada di tengah masyarakat. Sebagian masyarakat Indonesia yang beranekaragam suku dan budaya terpecah karena sikap kurang dewasa dalam menghadapi permasalahan sosial. Hal ini berakibat terhadap lunturnya nilai luhur bangsa Indonesia.

Budaya yang berasal dari luar Indonesia yang dianggap oleh sebagian orang benar justru bisa menimbulkan perpecahan dan gesekan dalam masyarakat. Menurut Sularso (2016:74), kearifan lokal (lokalitas) seringkali tergerus oleh tatanan gaya hidup yang di dalamnya mengandung nilai pragmatiskapitalistik. Seperti munculnya pergaulan bebas, penyalahgunan narkoba, pertikaian, korupsi, dan lain sebagainya. Bahkan, terkadang masyarakat lebih mempercayai berita palsu (hoax) yang tersebar di media sosial daripada fakta.

Mengenal kembali kearifan lokal dan budaya yang ada di suatu daerah akan membuat siswa menjadi mengingat kembali dari mana 
mereka berasal. Dengan mengetahui kearifan lokal dan budaya, akan membuat siswa menghargai dan mencintai daerah dan kebudayaannya. Menurut Sari (2015:2), proses pembelajarn dengan pendekatan kearifan lokal dan budaya bertujuan untuk menciptakan interaksi yang aktif, kreatif sehingga siswa dapat termotivasi dan dapat mempengaruhi hasil belajar siswa. Sebagai sebuah pendekatan pembelajaran, pendekatan KALBU perlu memiliki prinsip-prinsip antara lain: 1) student centered learning, 2) joyful learning, 3) meaningful learning, 4) sains skill, 5) meaningful learning dan 6) local wisdom and cultural learning.

Pada artikel ini akan dibahas mengenai salah satu kearifan lokal dan budaya di Kabupaten Purworejo. Salah satu budaya tersebut adalah Kesenian Tari Dolalak. Tari Dolalak merupakan tarian bentuk akulturasi budaya Barat (Belanda) dan budaya Jawa. Menurut Santosa (2013:230), awal munculya Tari Dolalak pada awal kolonialisme Belanda di Indonesia sekitar tahun 1915. Hal ini dapat dilihat dari beberapa aksesoris dan busana yang dikenakan mirip dengan seragam serdadu tentara Belanda saat itu. Tarian Dolalak juga memiliki gerak yang unik seperti kirig, ngetol, lilingan, dan sebagainya. Selain itu, disisipkan juga unsur magis di dalamnya. Kata Dolalak berasal dari lafal notasi nada do la la, yang merupakan notasi lagu diatonis yang dinyanyikan oleh serdadu-serdau Belana dalam tangsi (markas tentara). Para serdadu tersebut bernyanyi sambil menari, yang kemudian ditirukan oleh penduduk setempat (Purworejo). Dalam perkembangannya, tarian ini juga digunakan sebagai media dakwah agama Islam. Oleh karena itu, dalam sajian tariannya mengandung nilai-nilai agama dan norma-norma dalam masyarakat.

Biologi sebagai pembelajaran yang menggali alam sekitar sangatlah sesuai mengintegrasikan kearifan lokal dan budaya. Terdapat tiga (3) ranah kurikulum 2013 yang terkandung di dalam Tari Dolalak yaitu ranah sikap dan spiritual (afektif), ranah keterampilan (psikomotorik), dan ranah pengetahuan (kognitif). Oleh karena itu, artikel ini akan memaparkan 1) deskripsi perkembangan Tari Dolalak di Kabupaten Purworejo, 2) ranah nilai sikap, spiritual dan Penguatan Pendidikan Karakter (PPK) yang terkandung dalam Tari Dolalak, 3) nilai pengetahuan Tari Dolalak yang diintegrasikan dalam pelajaran Biologi.

\section{METODE PENELITIAN}

Metode penelitian merupakan studi pustaka dari beberapa literatur (analisis isi). Studi pustaka dilakukan dengan menganalisis mengenai kearifan lokal dan budaya di Kabupaten Purworejo yaitu Tari 
Dolalak. Kajian yang akan dilakukan meliputi:

1) Deskripsi perkembangan Tari Dolalak di Kabupaten Purworejo. Data diambil dari studi pustaka dan dideskripsikan.

2) Ranah nilai sikap, spiritual dan Penguatan Pendidikan Karakter (PPK) yang terkandung dalam Tari Dolalak. Data ini diambil dari studi pustaka kemudian dianalisis nilai-nilai yang terkandung dalam tari Dolalak. Ranah nilai sikap sosial dan spiritual ini ditelaah dengan mengambil sampel dari beberapa tembang dalam syair Dolalak. Di dalam tembang tersebut juga memuat Penguatan Pendidikan Karakter (PPK) Kurikulum 2013. Tembang yang akan dianalisis antara lain:
a. Jalan-jalan
b. Ambil kain
c. Pagi-pagi

3) Ranah nilai pengetahuan Tari Dolalak yang diintegrasikan dalam pelajaran Biologi. Data diambil dari studi pustaka mengenai perlengkapan (ubarampe) yang digunakan dalam Tari Dolalak dan gerakangerakan penari. Kemudian, dikaitkan dengan kompetensi dasar pada Biologi.

\section{HASIL DAN PEMBAHASAN}

A. Perkembangan Tari Dolalak di Kabupaten Purworejo

Kesenian Dolalak atau disebut Tari Dolalak merupakan kesenian rakyat yang tumbuh dan berkembang di Kabupaten Purworejo. Tarian ini menjadi kebanggaan masyarakat Purworejo karena memiliki kekhususan yang berbeda dengan kesenian budaya Jawa lainnya.

\section{Asal mula dan munculnya kesenian tari Dolalak}

Pada waktu bangsa Indonesia dijajah oleh Belanda, daerah Purworejo terkenal sebagai darah milisi (tempat melatih serdaduserdadu), di mana anggota milisi tersebut berasal dari penduduk lokal (setempat), baik dari Purworejo ataupun dari daerah lainnya. Mereka tinggal dalam tangsi/asrama. Serdadu-serdadu tersebut sering menghibur diri dengan menari, menyanyi diselingi dengan adegan pencak silat. Kebiasaan ini juga dilakukan di luar tangsi ketika istirahat. Hiburan ini sering dilihat oleh penduduk setempat, bahkan anak-anak kecil ikut meniru gerakan yang tidak beraturan tersebut. Terkadang disertai dengan gerakan dance, seperti yang dilakukan opsir Belanda. Singkat cerita, anak-anak dan penduduk setempat melihat dan mendengar not-not yang diucapkan oleh serdadu-serdadu yaitu hanya didengar kata Do La La. Berawal dari sini, maka oleh penduduk diberi 
nama menjadi DOLALAK. (Kandepdikbudcam, 1995: 1).

\section{Perkembangan Tari Dolalak}

Pada saat itu, rakyat di desa banyak memeluk agama Islam, maka untuk mengiringi digunakan rebana dan bedug. Selain itu, ada kentongan (tong-tong) dan kendang juga digunakan. Pada perkembangannya, Tari Dolalak juga diiringi oleh alat musik elektronik seperti keyboard.

Bahkan beberapa grup

Dolalak membuat kreasi tarian yang sedikit melenceng dari pakem (aturan) Dolalak. Hal ini menimbulkan pro dan kontra di kalangan dan seniman di Purworejo. Menurut Kandepdikbudcam (1995: 2-3), terdapat perbedaan Tari Dolalak pada awal mula Dolalak muncul hingga perkembangannya sekarang ir-syair yang berkembang disesuaikan dengan tema yang dikehendaki. Terkadang, syair-syair tersebut berkembang dengan lagu campursari. Namun, pada dasarnya terdapat syair-syair yang menjadi patokan dalam tari Dolalak. Syairsyair ini berisi nilai-nilai ajaran sosial masyarakat dan agama. Syairsyair tersebut antara lain: syair lagu jalan-jalan, syair lagu jalan-jalan keras, syair lagu ikan cucut, syair lagu pagi-pagi, syair lagu ambil kain, syair lagu saya cari, dan syair lagu kapal layar.

Tarian Dolalak juga memiliki gerakan-gerakan ciri khas. Menurut Sidik (1995:2-3), terdapat gerakangerakan antara lain:
1. Gerakan tangan dan jari.

Gerakan tangan dan jari meliputi: ukelan (pergelangan tangan diputar); grodha (letak tangan di depan perut); kesutan; lambaian; tepais (tepuk tangan sambil gedrug kaki); siak (besutan); dan malang kerik.

2. Gerakan kaki.

Gerakan kaki meliputi: jinjit; srisig; pencikan; sirig; gedrugan; palit (silang kaki); seredan (telapak kaki ditarik); dan sebagainya.

3. Gerakan leher.

Gerakan leher meliputi: tolehan; lilingan (kepala geleng); anthuk; coklekan; dan sebagainya.

4. Gerakan tubuh.

Gerakan tubuh meliputi: kirig; hoyogan; ngetol (gerakan pantat); glebagan (memutar arah tubuh); ngentrik/ngentrag dan sebagainya.

Tari Dolalak memiliki kostum yang unik yang mirip dengan serdadu Belanda. Hal ini yang menjadikan tarian ini berbeda dengan tarian dari daerah Jawa pada umumnya. Pada tabel 1, dikatakan bahwa kostum Dolalak meliputi: baju dan celana hitam. Pada baju dihias dengan warna-warna gemerlapan. Penari menggunakn pet (topi) seperti Marmaya, berkaos kaki panjang, berkacamata (umumnya hitam), dan sampur (selendang). Kostum ini mengalami perkembangan tetapi tetap pada pakem baju mirip serdadu Belanda. Perkembangan kostum Tari Dolalak disajikan pada gambar 1 . 
Tari Dolalak terdiri dari beberapa jenis tarian, antara lain: tari jalanjalan, tari ambil kain, tari jalan-jaln keras, tari syaiirela, tari kecilkecil, tari wulan sunu, tari itik-itik, tari semilah itu, tari pakola papan, tari bangilun,tari pakai nanti, tari berapa banyak, tari tinggi gunung, tari pagipagi, tari ikan cucut, tari saya cari, tari laju-lau, tari jikalau ada, tari jamjamuan, tari atas pisang, tari baju hitam, dan tari main-main.

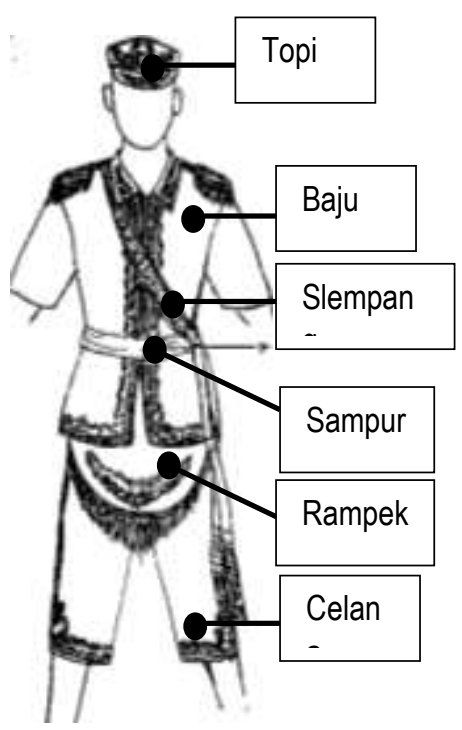

(a)

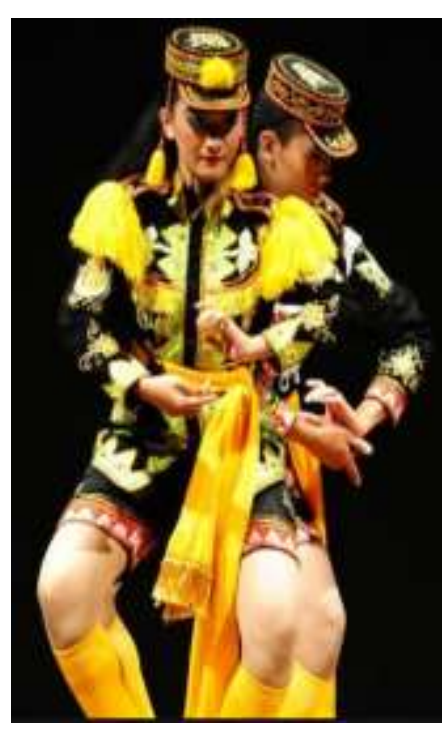

(b)

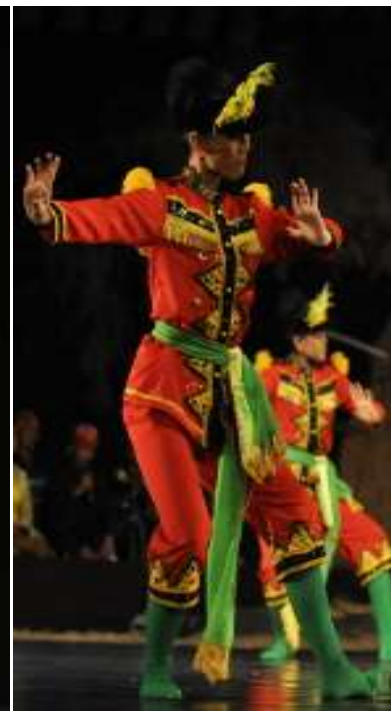

(c)

Gambar 1. Kostum tari Dolalak: a) Bagian kostum, b) dan c) Perkembangan Kostum Sumber: a) Kandepdikbudcam (1995:5); b) Dharma (https://alif.id); c) https://www.flickr.com

\section{B. Ranah sikap sosial dan spiritual pada kesenian tari Dolalak}

Dalam sebuah tari tentunya ada tembang atau syair yang mengiringi tarian tersebut. Tembang pada Tari Dolalak bila dihitung cukup banyak. Hal ini karena, tembang Dolalak dibuat berdasarkan tema tertentu. Namun, pada artikel ini hanya akan dibahas 3 (tiga) syair yaitu jalan-jalan, ambil kain, dan pagi-pagi. Dalam syair-syair tersebut mengandung nilai-nilai sikap sosial dan spiritual.

Ranah sikap tercantum dalam Kompetensi Inti (KI) 1 dan 2.
Menurut Adinugraha (2017:441), ranah sikap dibagi menjadi dua, yaitu sikap spiritual dan sikap sosial. Sikap spiritual terkait dengan pembentukan karakter siswa yang beriman dan bertakwa. Sikap sosial siswa terkait dengan pembentukan siswa yang berakhlak mulia, mandiri, demokratis, dan bertanggungjawab. Ranah sikap sosial meliputi jujur, disiplin, tanggung jawab, toleransi, gotong royong, santun, dan percaya diri.

Selain ranah sikap sosial dan spiritual, di dalam syair tersebut juga mengandung Penguatan Pendidikan 
Karakter (PPK). Menurut Pusat Analisis dan Sinkronisasi Kebijakan Sekertariat Jenderal Kemdikbud (2017:8-9), Penguatan Pendidikan Karakter (PPK) merupakan program pendidikan di sekolah untuk memperkuat karakter siswa melalui harmonisasi olah hati, olah rasa, olah pikir, dan olah raga dengan dukungan pelibatan publik dan kerjasama antara sekolah, keluarga, dan masyarakat yang merupakan bagian dari Gerakan Nasional Revolusi Mental (GNRM). Nilai karakter tersebut dikembangkan menjadi nilai utama antara lain: religius, nasionalis, mandiri, gotong royong, dan integritas.

Sikap sosial, spiritual dan penguatan pendidikan karakter menjadi suatu hal yang penting di tengah lunturnya adat ketimuran. Leluhur bangsa Indonesia memiliki warisan budaya yang mengandung nilai luhur manusia. Data mengenai analisis syair tersebut ditampilkan pada Tabel 2.

Tabel 2. Analisis syair pada tembang Dolalak

\begin{tabular}{|c|c|c|c|}
\hline No & Syair (bahasa Jawa) & $\begin{array}{c}\text { Ranah sikap } \\
\text { sosial dan } \\
\text { spiritual }\end{array}$ & $\begin{array}{c}\text { Penguatan } \\
\text { Pendidikan } \\
\text { Karakter } \\
\text { (PPK) }\end{array}$ \\
\hline \multirow[t]{2}{*}{1} & JALAN -JALAN & & \multirow[b]{2}{*}{$\begin{array}{l}\text { religius } \\
\text { nasionalis } \\
\text { integritas }\end{array}$} \\
\hline & $\begin{array}{l}\text { Pambukaning kidung minangka pambagya, } \\
\text { katur sagung para rawuh kang minulya } \\
\text { Miwah asung pudyastawa basukyarja, mugi } \\
\text { antuk sihing Hyang Maha Kuwasa }{ }^{2)} \\
\text { Mila ing wadaya dahat kumacelu, sung } \\
\text { sugata sepi kawruh sru balilu }{ }^{3)} \\
\text { Awit sedyaning nala sayekti amung, } \\
\text { amemetri kabudayan adiluhung }{ }^{4)} \\
\text { Punika ta wani wewujudanira, } \\
\text { kabudayan asli saking Purworejo } \\
\text { AMBIL KAIN }\end{array}$ & $\begin{array}{l}\text { 1) santun } \\
\text { 2) spiritualitas } \\
\text { 3) tanggung } \\
\text { jawab } \\
\text { 4) tanggung } \\
\text { jawab }\end{array}$ & \\
\hline & $\begin{array}{l}\text { Kembang mlathi pantes den agem pra putri, } \\
\text { ayo ngudi kagunan kita pribadi }{ }^{1)} \\
\text { Kembang menur megar anjrah kadya sawur, } \\
\text { muji sukur mrih rukuning para sedulur }{ }^{2)} \\
\text { Kembang mawar megar gandane angambar, } \\
\text { samya sabar anggayuh kawruh kang anyar }{ }^{3} \\
\text { Kembang gambir arum gandane sumilir, aja }\end{array}$ & $\begin{array}{l}\text { 1) tanggung } \\
\text { jawab } \\
\text { 2) toleransi } \\
\text { 3) santun } \\
\text { 4) percaya diri } \\
\text { 5) disiplin, } \\
\text { percaya diri }\end{array}$ & $\begin{array}{l}\text { religius } \\
\text { nasionalis } \\
\text { mandiri } \\
\text { gotong royong } \\
\text { integritas }\end{array}$ \\
\hline
\end{tabular}




\begin{tabular}{lll}
\hline${\text { kibir kawruh kang durung } \text { kalair }^{4)}}$ & 6) tanggung \\
Kembang suruh mbalasah saengaga uwuh, & jawab \\
kudu teguh ngadhepi baya pakewuh ${ }^{5)}$ & 7) tanggung \\
Kembang jambe arum mencit panggonane, & jawab \\
aja rame lamun lagya tandang gawe & \\
Kembang soka megare kaya tinata, angudiya & \\
rahayuning nusa bangsa & \\
3 & PAGI PAGI
\end{tabular}

Pancasila minangka dhasar negara

Den estokna kanthi tulusing wardaya ${ }^{\text {I) }}$

Kang kapisan kita nembah mring Pangeran

Sing Suprihe kita tansah ingayoman ${ }^{2)}$

Kapindhone sila dhasar kamanungsan

Kita kabeh kudu darbe among rasa ${ }^{3)}$

Kaping telu sila dhasar persatuan

Kabeh suku nunggal dadya sagolongan ${ }^{4)}$

Kaping pate sila dhasar kerakyatan

Kita kabeh iku darbe panguwasa ${ }^{5)}$

Kalimane sila dhasar keadilan

Bangsa kita nggayuh adil paramarta ${ }^{6)}$
1) tanggung
jawab
2) spiritual, santun, jujur
3) toleransi
4) toleransi, gotong royong
5) gotong
royong
6) tanggung
jawab

religius

nasionalis

gotong royong

Syair lagu "Jalan-Jalan"

merupakan tarian pembuka dalam Dolalak yang diartikan sebagai bentuk penghormatan ucapan salam kepada tamu, semoga tamu mendapat berkat dan rahmat dari Tuhan (baris 1 sampai 4, yang mengandung nilai santun dan spiritual. Baris 5 sampai 10 mengatakan bahwa ada sedikit pengetahuan dengan tujuan untuk memberi tahu untuk melestarikan kebudayaan besar yaitu kebudayaan Purworejo, yang mengandung nilai tanggung jawab untuk melestarikan kebudayaan Dolalak. Syair lagu "Jalan-Jalan" ini juga memuat Penguatan Pendidikan Karakter meliputi religius, nasionalis, dan integritas.
Syair lagu "Ambil Kain" menjelaskan bahwa manusia perlu mencari potensi diri sendiri (baris 1 dan 2), yang memiliki nilai tanggung jawab untuk mengembangkan potensi kita. Baris 3 dan 4 menjelaskan bahwa manusia perlu bersyukur demi kerukunan sesama saudara, yang memiliki nilai toleransi antar sesama. Kemudian baris 5 dan 6 menjelaskan bahwa manusia harus sabar untuk mencapai pengetahuan baru, yang memiliki nilai santun. Selanjutnya baris 7 dan 8 menjelaskan bahwa mencegah untuk terpengaruh oleh pengetahuan semu (tidak nyata), yang memiliki nilai percaya diri untuk berpegang pada pengetahuan sesuai fakta. Baris 
9 dan 10 menjelaskan bahwa manusia harus teguh menghadapi masalah yang dirasakan tidak enak, yang memiliki nilai disiplin dan percaya diri. Baris 11 sampai 14 menjelaskan bahwa manusia jangan banyak bicara ketika bekerja dan harus mencari keselamatan nusa dan bangsa, yang memiliki nilai tanggung jawab. Syair "Ambil Kain" ini juga memuat Penguatan Pendidikan Karakter meliputi religius, nasionalis, mandiri, gotong royong, dan integritas.

$$
\text { Syair "Pagi-Pagi" }
$$

menjelaskan bahwa Pancasila adalah dasar negara yang harus dilaksanakan dengan sepenuh hati (baris 1 dan 2), yang memiliki nilai tanggung jawab untuk melaksanakan Pancasila sebagai dasar negara. Baris 3 dan 4 menjelaskan bahwa manusia harus menyembah kepada Tuhan (Pangeran) agar selalu mendapat perlindungan dari Tuhan, yang memiliki nilai spiritual, santun, dan jujur. Kemudian, baris ke 5 dan 6 menjelaskan sila kemanusiaan bahwa manusia harus memiliki rasa menolong terhadap sesama, yang memiliki nilai toleransi. Selanjutnya, baris 7 dan 8 menjelaskan sila persatuan bahwa semua suku (dan agama) harus bersatu menjadi satu golongan, yang memiliki nilai toleransi dan gotong rotong. Baris 9 dan 10 menjelaskan sila kerakyatan bahwa manusia memiliki hak kekuasaan (pemimpin dan dipimpin). Baris 11 dan 12 menjelaskan sila keadilan bahwa bansa Indonesia akan menuju adil dan makmur. Syair "Pagi-Pagi" ini juga memuat Penguatan Pendidikan Karakter meliputi religius, nasionalis, gotong royong, dan integritas.

\section{Ranah pengetahuan dan keterampilan pada kesenian tari Dolalak}

Ranah pengetahuan atau disebut dengan kognitif adalah ranah untuk mengukur kemampuan siswa mulai dari tingkat pemahaman hingga analisis ( $\mathrm{C} 1$ hingga $\mathrm{C} 4$ pada taksonomi bloom). Ranah pengetahuan yang dimaksud dalam artikel ini adalah mata pelajaran Biologi.

Ranah keterampilan atau disebut dengan psikomotorik adalah ranah yang berkaitan dengan keterampilan (skill) atau kemampuan bertindak setelah siswa menerima pengalaman belajar dan biasanya berkaitan dengan aktivitas fisik. Contoh aktivitas seperti presentasi, praktikum, membuat proyek, dan diskusi. Pada dasarnya, pelajaran lain juga bisa terkait seperti seni, agama, bahasa daerah, dan pendidikan kewarganegaraan. Namun, artikel ini hanya dibatasi pada mata pelajaran Biologi.

Ranah $\begin{aligned} & \text { pengetahuan dan } \\ & \text { tergambar dalam } \\ & \text { keterampilan }\end{aligned}$
kompetensi dasar KI 3 dan KI $4 .$.


Pada bagian ini yang dianalisis adalah gerakan dan perlengkapan Tari Dolalak. Materi yang dapat

Tabel 3. Analisis Tari Dolalak dengan materi Biologi diintegrasikan dalam Tari Dolalak disajikan pada tabel 3 sebagai berikut

\begin{tabular}{|c|c|c|c|}
\hline No & Tari Dolalak & Bab & Kompetensi Dasar \\
\hline \multirow[t]{5}{*}{1} & $\begin{array}{l}\text { Ubarampe } \\
\text { (perlengkapan } \\
\text { sesaji) meliputi: } \\
\text { Ingkung bakar, } \\
\text { Degan/ kepala } \\
\text { muda, rokok } \\
\text { menyan, nasi } \\
\text { tumpeng lengkap, } \\
\text { telur ayam } \\
\text { kampung, minuman } \\
\text { kopi, minuman teh, } \\
\text { kembang telon } \\
\text { (mawar ungu, }\end{array}$ & $\begin{array}{l}\text { Keanekaragam } \\
\text { an Hayati } \\
\text { Kelas X }\end{array}$ & $\begin{array}{l}\text { 3.2. Menganalisis data hasil observasi } \\
\text { tentang berbagai tingkat } \\
\text { keanekaragaman hayati (gen, jenis dan } \\
\text { ekosistem) di Indonesia. } \\
\text { 4.2. Menyajikan hasil identifikasi usulan } \\
\text { upaya pelestarian keanekaragaman } \\
\text { hayati Indonesia berdasarkan hasil } \\
\text { analisis data ancaman kelestarian } \\
\text { berbagai keanekaragaman hewan dan } \\
\text { tumbuhan khas Indonesia yang } \\
\text { dikomunikasikan dalam berbagai bentuk } \\
\text { media informasi. }\end{array}$ \\
\hline & $\begin{array}{l}\text { mawar putih, } \\
\text { mawar merah), tebu } \\
\text { wulung, janur } \\
\text { kuning, dan bedug } \\
\text { (Pangalia, 2015:37) }\end{array}$ & $\begin{array}{l}\text { Plantae } \\
\text { Kelas X }\end{array}$ & $\begin{array}{l}\text { 3.7. Menerapkan prinsip klasifikasi } \\
\text { untuk menggolongkan tumbuhan ke } \\
\text { dalam divisio berdasarkan pengamatan } \\
\text { morfologi dan metagenesis tumbuhan } \\
\text { serta mengaitkan peranannya dalam } \\
\text { kelangsungan kehidupan di bumi. }\end{array}$ \\
\hline & & & $\begin{array}{l}\text { 4.7. Menyajikan data tentang morfologi } \\
\text { dan peran tumbuhan pada berbagai } \\
\text { aspek kehidupan dalam bentuk laporan } \\
\text { tertulis. }\end{array}$ \\
\hline & & $\begin{array}{l}\text { Animalia } \\
\text { Kelas X }\end{array}$ & $\begin{array}{l}\text { 3.8. Menerapkan prinsip klasifikasi } \\
\text { untuk menggolongkan hewan ke dalam } \\
\text { filum berdasarkan pengamatan anatomi } \\
\text { dan morfologi serta mengaitkan } \\
\text { peranannya dalam kehidupan. }\end{array}$ \\
\hline & & & $\begin{array}{l}\text { 4.8. Menyajikan data tentang } \\
\text { perbandingan kompleksitas jaringan } \\
\text { penyusun tubuh hewan dan perannya } \\
\text { pada berbagai aspek kehidupan dalam } \\
\text { bentuk laporan tertulis. }\end{array}$ \\
\hline 2 & Gerakan-gerakan & Sistem Gerak & 3.5. Menganalisis hubungan antara \\
\hline
\end{tabular}




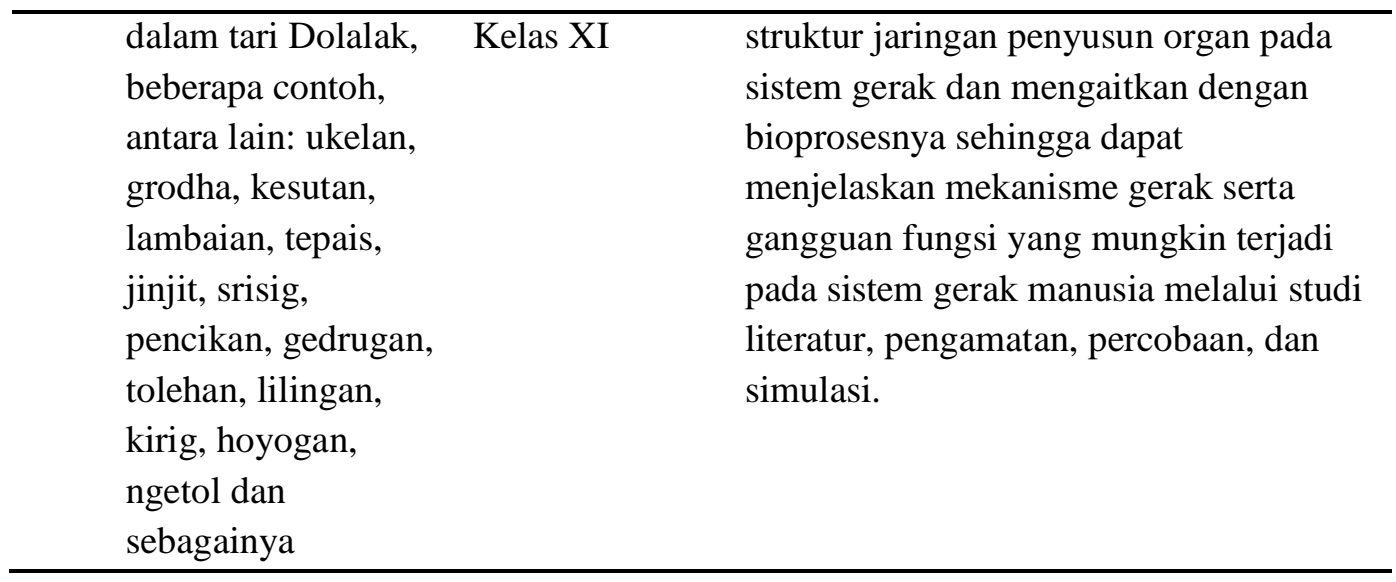

Pembelajaran Biologi Bab Keanekaragaman Hayati dapat mengambil contoh pada sesaji Tari Dolalak yaitu kembang telon (bunga tiga warna) yaitu mawar putih, mawar merah dan mawar ungu). Siswa dapat menjelaskan ketiga bunga mawar tersebut termasu keanekaragaman spesies karena memiliki nama spesies yang berbeda walaupun memiliki nama bunga mawar.

Pembelajaran Biologi Bab Plantae dapat didesain dengan mengelompokkan tumbuhan yang digunakan dalam sesaji Tari Dolalak ke dalam kelompok dikotil (magnoliopsida) dan kelompok monokotil (liliopsida). Selain itu, siswa dapat diajak untuk memahami karakteristik dari tumbuhan dan manfaat lain selain digunakan sebagai sesaji.

Pembelajaran Biologi Bab Animali dapat mengambil contoh pada hewan yang dimanfaatkan dalam sesaji seperti ayam yang digunakan dalam tumpeng. Selain itu, siswa dapat memahami manfaat hewan dalam kebudayaan seperti penggunaan kulit sapi pada pembuatan bedug yang digunakan sebagai alat musik Dolalak.

Pembelajaran Biologi Bab

Sistem Gerak dapat dijelaskan dengan nama pergerakan sendi seperti elevasi-depresi, supinasipronasi, abduksi-aduksi, dan fleksiekstensi. Gerakan Tari Dolalak disajikan pada tabel 4. Namun, tidak semua gerakan ditampilkan dalam tabel. Hal ini karena banyak gerakan yang terdapat di dalam tari Dolalak. Gerakan yang disajikan pada tabel antara lain: miwir sampur, pencikan, dan ukel wolak walik. 
Tabel 4. Analisis Gerakan Tari Dolalak pada Materi Sistem Gerak

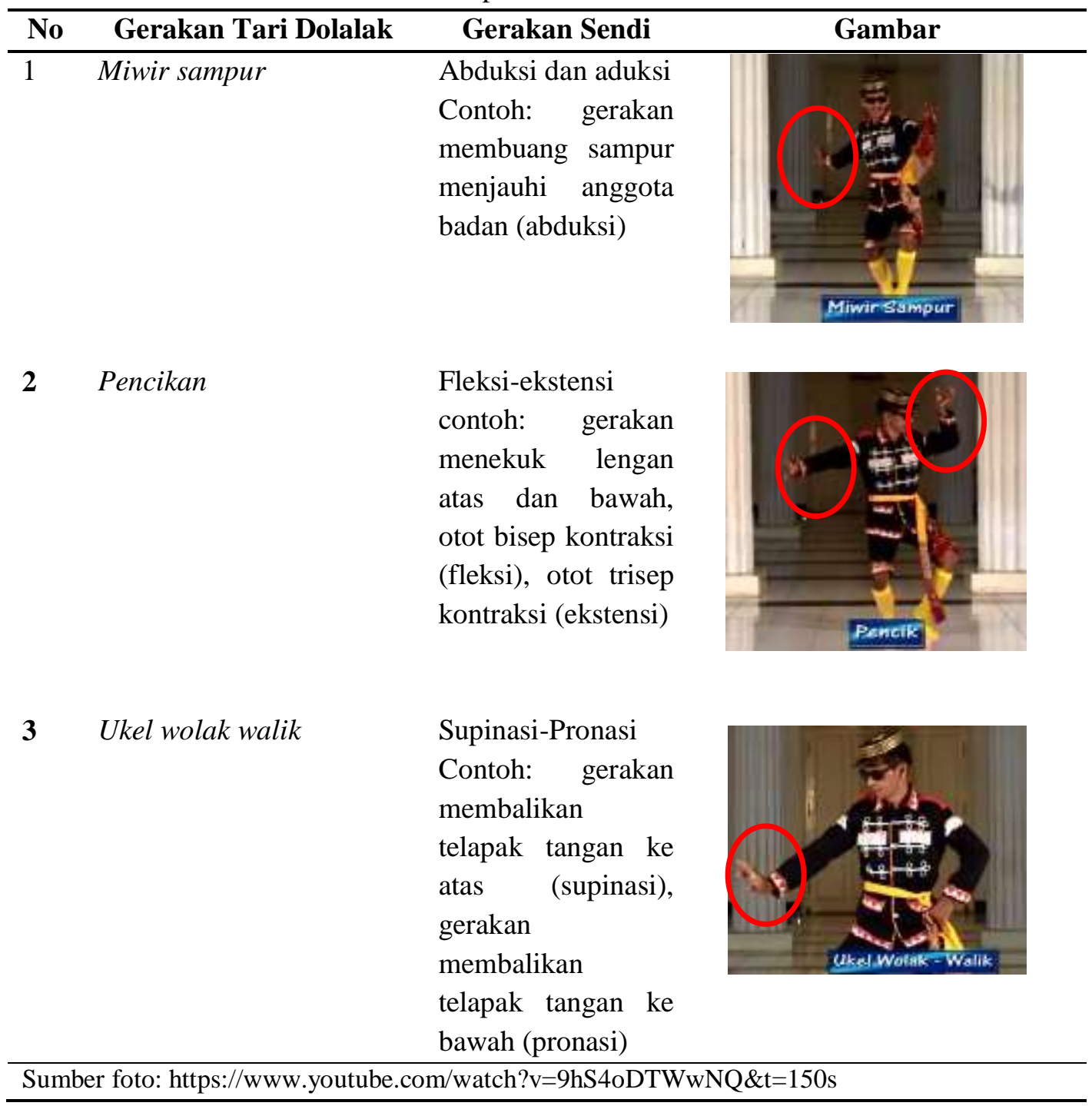




\section{KESIMPULAN}

Berdasarkan pembahasan di atas, maka simpulan dalam artikel ini adalah sebagai berikut.

1. Tari Dolalak merupakan tari yang berasal dari Kabupaten Purworejo yang merupakan bentuk akulturasi budaya. Tari Dolalak mengalami perkembangan antara lain: 1) jenis tarian, 2) syair, 3) pakaian/ kostum, 4) formasi pemain, dan 5) pementasan.

2. Berdasarkan analisis 3 (tiga) syair Dolalak yaitu Jalan-Jalan, Ambil Kain, dan Pagi-Pagi, maka dapat dijelaskan bahwa Tari Dolalak mengandung nilainilai yang terkandung dalam Kurikulum 2013 yaitu ranah sikap sosial dan spiritual (KI1 dan KI2) yaitu jujur, disiplin, tanggung jawab, toleransi, gotong royong, santun, dan percaya diri. Selain itu, mengandung nilai Penguatan Pendidikan Karakter (PPK) yaitu religius, nasionalisme, mandiri, gotong royong, dan integritas.

3. Berdasarkan analisis gerakan dan perlengkapan Tari Dolalak, maka dapat dijelaskan bahwa Tari Dolalak dapat diintegrasikan dalam ranah pengetahuan (KI 3) dan keterampilan (KI 4). Ranah pengetahuan dan keterampilan ini meliputi materi keanekaragaman hayati, plantae, animalia, dan sistem gerak.

\section{REFERENSI}

Adinugraha F. (2017). Pengaruh model pembelajaran dan efikasi diri terhadap sikap ilmiah siswa sma peminatan mipa. Jurnal ProLife. 4 (3) : 441-455.

Kandepdikbudcam. (1995). Hasil penataran muatan lokal dolalak. Purworejo: Kandepdikbudcam.

Pangalia RT. (2015). Strategi komunikasi kesenian tari dolalak di kabupaten purworejo. Skripsi. Online at http://repository.uksw.edu.

Pieter J. (2017). Pembelajaran ipa berbasis kearifan lokal sebagai solusi pengajaran ipa di daerah pedalaman provinsi papua. On line https://www.researchgate.net 1-11 [diakses 15 Mei 2018].

Pusat Analisis dan Sinkronisasi Kebijakan Sekertariat Jenderal Kemdikbud. (2017). Penguatan pendidikan karakter. Jakarta: Kemdikbud.

Santosa DH, Timbul Haryono, R.M. Soedarsono. (2013). Seni dolalak purworejo jawa tengah: peran perempuan dan pengaruh islam dalam seni pertunjukan. Jurnal Kawistara 3 (22) : 228 - 241.

Sari JR, Kartimi Kartimi, dan Eka Fitriah. (2015). Penerapan pembelajaran biologi berbasis sains budaya lokal kesenian sintren pada konsep spermatophyta untuk meningkatkan keterampilan 
berpikir kritis siswa sma $\mathrm{n} 1$ ciwaringin 5 (1) : 1 - 12 .

Sidik AS dan Rebino Tjiptosiswoyo. 1995. Seni tari dolalak sebagai pegangan dalam memberikan pelajaran seni tari dolalak (muatan lokal kabupaten purworejo). Purworejo: Depdikbud Purworejo.

Sularso S. (2016). Revitalisasi kearifan lokal dalam pendidikan dasar. Jurnal Pendidikan Sekolah Dasar 2 (1) : 74 - 79. 